\title{
IODP Expedition 323-Pliocene and Pleistocene Paleoceanographic Changes in the Bering Sea
}

\author{
by Kozo Takahashi, A. Christina Ravelo, Carlos Alvarez Zarikian, \\ and the IODP Expedition 323 Scientists
}

\begin{abstract}
High-resolution paleoceanography of the Plio-Pleistocene is important in understanding climate forcing mechanisms and the associated environmental changes. This is particularly true in high-latitude marginal seas such as the Bering Sea, which has been very sensitive to changes in global climate during interglacial and glacial or Milankovitch time scales. This is due to significant changes in water circulation, land-ocean interaction, and sea-ice formation. With the aim to reveal the climate and oceanographic history of the Bering Sea over the past $5 \mathrm{Ma}$, Integrated Ocean Drilling Program (IODP) Expedition 323 cored a total of 5741 meters of sediment (97.4\% recovery) at seven sites covering three different areas: Umnak Plateau, Bowers Ridge, and the Bering slope region. Four deep holes range from $600 \mathrm{~m}$ to
\end{abstract}

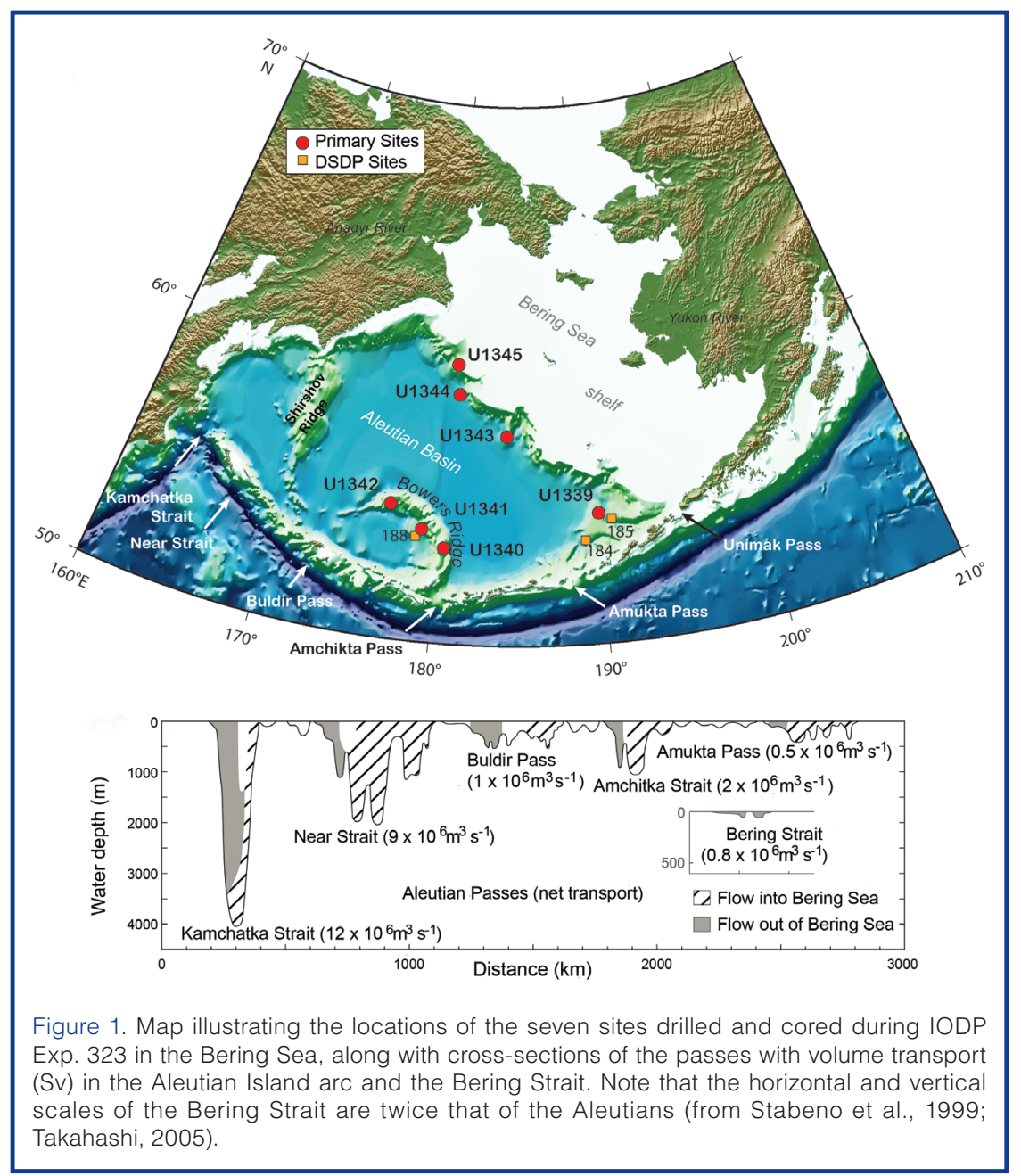

$745 \mathrm{~m}$ spanning in age from 1.9 Ma to $5 \mathrm{Ma}$. The water depths (819 $\mathrm{m}$ to $3173 \mathrm{~m}$ ) allow characterization of past vertical water mass distribution such as the oxygen minimum zone (OMZ). The results highlight three key points. (1) The first is an understanding of long-term evolution of surface-water mass distribution during the past $5 \mathrm{Ma}$ including past sea-ice distribution and warm and less eutrophic subarctic Pacific water mass entry into the Bering Sea. (2) We characterized relatively stagnant intermediate water mass distribution imprinted as laminated sediment intervals that have been ubiquitously encountered. Today, the $\mathrm{OMZ}$ impinges upon the sediments at $700-1600 \mathrm{~m}$ water depths. In the past, the $\mathrm{OMZ}$ appears to have occurred mainly during interglacial periods. Changes in low oxygen-tolerant benthic foraminiferal faunas clearly concur with this observation. (3) We also characterized significant changes between glacial episode of terrigenous sedimentary supply and interglacial episode of diatom flux.

\section{Introduction and Goals}

The rate and regional expression of recent global warming is difficult to understand and even more difficult to predict because of the complex nature of the climate system, whose components interact nonlinearly with various time lags and on various timescales. Paleoclimatic and paleoceanographic studies provide opportunities to study the dynamics of the climate system by examining how it responds to external forcing (e.g., greenhouse gases and solar radiation changes) and how it generates internal variability due to interacting Earth-system processes. Of note is the amplified recent warming of the high latitudes in the Northern Hemisphere (Solomon et al., 2007), which is presumably related to sea-ice albedo feedback and teleconnections to other regions; both the behavior of sea ice-climate interactions and the role of large-scale atmospheric and oceanic circulation in climate change can be studied with geologic records of past climate changes in the Bering Sea. 
Prior to IODP Expedition 323 (Exp 323 hereafter), little was known about the sedimentology and climate history of the Bering Sea outside of a few piston core studies (Cook et al., 2005; Okazaki et al., 2005; Katsuki and Takahashi, 2005; Takahashi et al., 2005) and Sites 188 and 185 (Scholl and Creager, 1973), which were drilled by the Deep Sea Drilling Project (DSDP) in 1971 with old drilling technology and poor recovery. Past studies using piston cores in the Bering Sea indicated that, while current conditions in the Bering Sea promote seasonal sea-ice formation, during the Last Glacial Maximum (LGM) conditions sustained perennial or nearly perennial sea-ice cover (Tanaka and Takahashi, 2005), attesting to the potential utility of sedimentary records in the Bering Sea to examine past sea-ice distributions. In paleoceanographic studies of the North Pacific, the Bering and Okhotsk seas have been implicated as sources of dense oxygenated intermediate water that possibly impacted oceanic and climate conditions throughout the Pacific on glacial-interglacial (Gorbarenko, 1996; Matsumoto et al., 2002) and millennial (Hendy and Kennett, 2003) timescales. In addition, changes in Bering Sea environmental conditions could be related to sea-level and circulation changes, which alter flow patterns through narrow straits that connect the Bering Sea to the Arctic Ocean to the north and the Pacific Ocean to the south. The lack of pertinent Bering Sea material prevented the evaluation of these and other ideas for a long time.

The scientific objectives of Exp 323 are as follows: (1) to elucidate a detailed evolutionary history of climate and surface ocean conditions since the earliest Pliocene in the Bering Sea, where amplified high-resolution changes of climatic signals are recorded; (2) to shed light on temporal changes in the origin and intensity of North Pacific Intermediate Water (NPIW) and possibly deeper water mass formation in the Bering Sea; (3) to characterize the history of continental glaciation, river discharge, and sea ice formation in order to investigate the link between continental and oceanic conditions in the Bering Sea and on adjacent land areas; (4) to investigate linkages through comparison to pelagic records between ocean/climate processes that occur in the more sensitive marginal sea environment and processes that occur in the North Pacific and/or globally (This objective includes evaluating how the ocean/climate history of the Bering Strait gateway region may have affected North Pacific and global conditions.); and (5) to constrain global models of subseafloor biomass and microbial respiration by quantifying subseafloor cell abundance and pore water chemistry in an extremely high productivity region of the ocean. We also aim to determine how subseafloor community composition is influenced by high productivity in the overlying water column.

Seven sites whose terrigenous and biogenic components capture the spatial and temporal evolution of the Bering Sea through the Pliocene and Pleistocene* were successfully drilled with a total core length of $5741 \mathrm{~m}$ during Exp 323 (Expedition 323 Scientists, 2010; Takahashi et al., 2011; Fig. 1; Table 1). Additionally, Exp 323 collected a rich archive of information regarding the role of microbes on biogeochemical cycles in ultra-high-productivity environments, the postdepositional processes that impact geochemical, lithologic, and physical properties of the sediment, and past oceanic chemistry preserved in pore waters. This paper presents background on environmental setting and important scientific questions concerning the Bering Sea, followed by pertinent highlights of the scientific findings of Exp 323 mostly obtained onboard JOIDES Resolution during the cruise.

*Note: In this paper we opt to continue using the last major published timescale, in which the base of the Pleistocene is defined by the Global Boundary Stratotype Section and Point (GSSP) of the Calabrian Stage at 1.806 (1.8) Ma (Gradstein et al., 2004).

\section{Geological and Physical Setting}

With an area of $2.29 \times 10^{6} \mathrm{~km}^{2}$ and a volume of $3.75 \times 10^{6} \mathrm{~km}^{3}$, the Bering Sea is the third largest marginal sea in the world, surpassed only by the Mediterranean and South China seas (Hood, 1983). Approximately half of the Bering Sea is a shallow $(0-200 \mathrm{~m})$, neritic environment, with the majority of the continental shelf spanning the eastern side of the basin off Alaska from Bristol Bay to the Bering Strait (Fig. 1). The northern continental shelf is seasonally ice-covered, but little ice forms over the deep southwest areas. In addition to the shelf regions, two significant topographic highs have better $\mathrm{CaCO}_{3}$ preservation than the deep basins. First is the Shirshov Ridge, which extends south of the Koryak Range in eastern Siberia along $170^{\circ} \mathrm{E}$ and separates the southwestern part of the Bering Sea into two basins, Komandorski (to the west) and Aleutian (to the east). Second is the Bowers Ridge, which extends $300 \mathrm{~km}$ north from the Aleutian Island arc (Fig. 1). The Aleutian Basin is a vast plain 3800-3900 m deep with occasional gradually sloping depres-sions as deep as $4151 \mathrm{~m}$ (Hood, 1983). 
Three major rivers flow into the Bering Sea; the Kuskokwim and Yukon rivers drain central Alaska, and the Anadyr River drains eastern Siberia (Fig. 1). The Yukon is the longest of the three rivers and supplies the largest discharge into the Bering Sea. Its discharge peaks in August because of meltwater and is about equal to that of the Mississippi. It has a mean annual flow of $5 \times 10^{3} \mathrm{~m}^{3} \mathrm{~s}^{-1}$ (Hood, 1983).

Today, a substantial amount of water is transported in and out of the Bering Sea across the Aleutian Island arc and the Bering Strait through passes (Fig. 1). Water mass exchange with the Pacific through the Aleutian Islands, such as through the Kamchatka Strait, is significant, linking Bering Sea conditions to the Pacific climate. The Alaskan Stream, an extension of the Alaskan Current, flows westward along the Aleutian Islands and enters the Bering Sea partially through the Amchitka Strait and to significant extent through the Near Strait west of Attu Island in the eastern Aleutian Islands (Fig. 1). A part of the Subarctic Current also joins the Alaskan Stream, resulting in a combined volume transport of $11 \mathrm{~Sv}\left(0.011 \mathrm{~km}^{3} \mathrm{~s}^{-1}\right)$ (Ohtani, 1965).

Bottom and intermediate water in the Bering Sea originates from the North Pacific. After flowing into the Bering Sea it is slightly modified by the mixing of relatively fresh, warm water with very small amounts of bottom water formed within the Bering Sea today (Warner and Roden, 1995). Nutrient concentrations of North Pacific origin are high compared to all other regions in the global oceans; this explains the high productivity in the surface layers and consequent very low oxygen concentrations in intermediate and deep water masses of the Bering Sea today (Fig. 2). The oxygen and nutrient composition of the Bering Sea waters is further modified by denitrification (Lehmann et al., 2005)
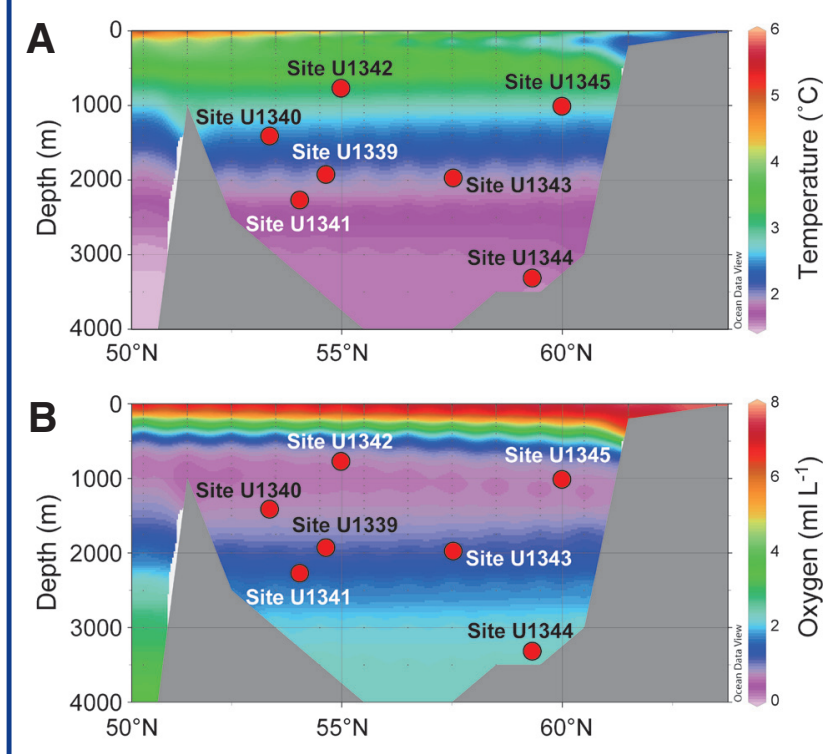

Figure 2. Vertical profiles of [A] temperature and [B] dissolved oxygen along the transect on $180^{\circ}$ meridian line in the Bering Sea (data from World Ocean Atlas (2005); figures drawn by Ocean Data View). and respiration of organic matter in the water column (Nedashkovskiy and Sapozhnikov, 1999). Respiration and the development of an $\mathrm{OMZ}$ are particularly intense at water depths of $1000 \mathrm{~m}$ (Fig. 2).

Much of the Pacific water entering the Bering Sea is matched by outflow through the Aleutian Islands. The most significant outflow is through the Kamchatka Strait, which has a maximum depth of $4420 \mathrm{~m}$ (Stabeno et al., 1999) (Fig. 1). If some component of NPIW or deep water formed in the Bering Sea in past times, particularly when sea level was lower, it would have flowed out through the Kamchatka Strait or a secondary outlet near the Commander-Near Strait at 2000 m (Fig. 1).

The unidirectional northward transport of water masses $(0.8 \mathrm{~Sv})$ from the Bering Sea through the Bering Strait to the Arctic Ocean contributes to the salinity and biogeochemical contrast between the Pacific and the Atlantic. The Bering Strait region is one of the most biologically productive regions in the world (Sambrotto et al., 1984). Much of this biologically produced organic matter and the associated nutrients flow into the Arctic Ocean because of the northward current direction. This may profoundly influence the present dominance of carbonate production in the Atlantic versus opal production in the Pacific, as described by models of basin-to-basin fractionation (Berger, 1970) and "carbonate ocean vs. silica ocean" (Honjo, 1990). Flow through the Bering Strait, which is $\sim 50 \mathrm{~m}$ deep today (Fig. 1), was certainly different at times of lower sea level or enhanced perennial sea-ice cover. The closing of this gateway and the accompanying changes in ocean and river flow through time could have caused changes in global patterns of circulation or in nutrient and salinity distributions.

\section{Ages and Sedimentation Rates}

Among the three drill sites explored in the Bowers Ridge region, both of the deepest holes drilled-Hole U1340A (605 $\mathrm{m}$ uncompressed core depth below seafloor (CSF-A), hereafter meters below seafloor (mbsf) and Hole U1341B (600 m mbsf)-represent the time spans from the Holocene to the Pliocene, back to $\sim 5 \mathrm{Ma}$ and $4.3 \mathrm{Ma}$, respectively (Table 1; Fig. 3). Note that the $4.3 \mathrm{Ma}$ bottom age of Hole U1341B has been revised by an onshore study from the shipboard data ( $\sim \mathrm{Ma}$; Expedition 323 Scientists, 2010; Takahashi et al., 2011). The expedition's initial goal of penetrating to $\sim 5 \mathrm{Ma}$ was adequately accomplished at Site U1340, despite the failure of the extended core barrel (XCB) cutting shoe in Hole U1340A, which target depth of penetration was $700 \mathrm{~m}$. In the gateway region sites (at the Bering slope), two deep holes were drilled: Holes U1343E (744 m mbsf) and U1344A (745 m mbsf). Hole U1343E reached $\sim 2.4 \mathrm{Ma}$, where as Hole U1344A reached $\sim 1.9 \mathrm{Ma}$ (Figs. 3 and 4). Also note that the $2.4 \mathrm{Ma}$ bottom age of Hole U1344A has been revised by an onshore study from the shipboard data (2.1 Ma). At other drill sites, the bottom ages of 


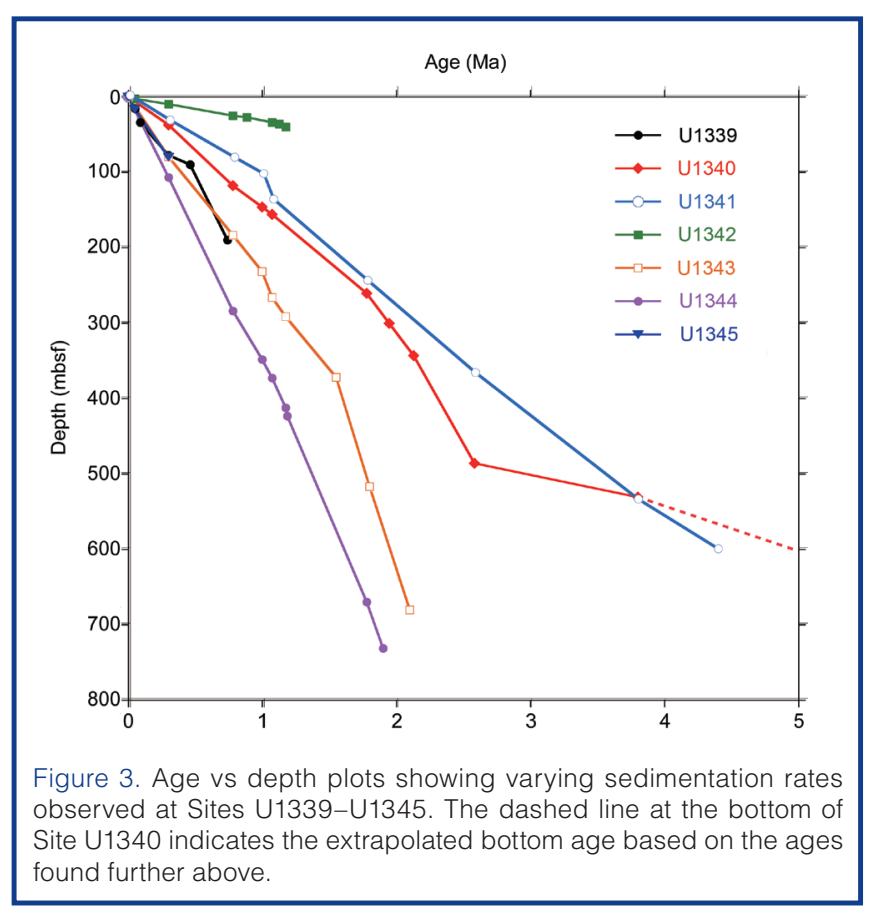

the sedimentary sequences based on biomagnetostratigraphy are as follows: Site U1339 at Umnak Plateau reached $0.74 \mathrm{Ma}$, Site U1342 at Bowers Ridge reached 1.2 Ma (with the exception of the middle Miocene sediments just above the basement), and Site U1345 at Bering slope reached $0.5 \mathrm{Ma}$ (Table 1).

The sediments recovered from Bowers Ridge display high mean sedimentation rates $\left(\sim 12 \mathrm{~cm} \mathrm{k.y.}{ }^{-1}\right.$ at Sites U1340 and U1341) without apparent hiatuses, and are generally appropriate for high-resolution Pliocene-Pleistocene paleoceanographic studies with adequate calcareous benthic foraminiferal preservation in the Pleistocene, but lower preservation in the Pliocene. On the other hand, sediments at these sites are generally barren of planktonic foraminifera and calcareous nannofossils except for the section between $\sim 2.5 \mathrm{Ma}$ and $\sim 3 \mathrm{Ma}$. The abundance of all siliceous microfossils is generally high, enabling good biostratigraphy and paleoceanographic reconstruction. Furthermore, the upper part of Site U1340 ( 20-150 m uncompressed core composite depth, CCSF-A) had obvious soft-sediment deformation due to mass movement possibly caused by local seismic activity. Although such deformation hinders the continuous reconstruction of late Pleistocene high-resolution paleoceanography at this site, information from other drill sites can readily fill the gap.

In the region of the Arctic gateway sites proximal to the Bering slope, the observed sedimentation rates were overwhelmingly high: Hole U1343E had sedimentation rates of 21-58 cm k.y. ${ }^{-1}$ and Hole U1344A had rates of 29-50 cm k.y. ${ }^{-1}$. Sedimentation rates were so high, in fact, that drilling reached ages of only 2.4 Ma and 1.9 Ma, respectively, despite penetration to $745 \mathrm{~m}$ mbsf at each site. Such high sedimentation rates stem from the deposition of silt and clay transported by the Yukon and other rivers as well as the terrigenous sediments once deposited on the shelf. In spite of the high percentage of terrigenous material, pertinent biotic proxies including benthic foraminifera and siliceous microfossils are adequately preserved, enabling future paleoceanographic studies. Therefore, the overall coverage of excellent cores to $\sim 5 \mathrm{Ma}$ in the Bowers Ridge region and $\sim 2 \mathrm{Ma}$ in the gateway region allows detailed, continuous high-resolution paleoceanographic studies relevant to global climate change.

\section{Depositional Environments and Lithology}

The seven sites drilled during Exp 323 provide a continuous high-resolution record of the evolution of marine sedimentation in the marginal Bering Sea (Fig. 4). Overall, the sediments recovered in the Bering Sea are a mixture of three components: biogenic, siliciclastic, and volcaniclastic. Other accessory lithologies identified include authigenic carbonates (dolomite Fe-rich carbonates and $\mathrm{Mg}$ calcite), barite and sulfides. The most prominent sedimentary features observed were decimeter- to meter-scale bedded alternations of sediment color and texture, reflecting alternations in lithology between more siliciclastic and more biosiliceous deposits (Fig. 4). The sediments were generally highly bioturbated. However, fine laminations preserving alternations between millimeter-scale laminae of biogenic and terrigenous material were also present in several of the drilled sites (Fig. 5).

The distributions of the sedimentary components and sedimentary structures, and their variability both within and between the Exp 323 sites account for changes of the biogenic, glaciomarine, terrigenous, and volcanogenic sediment sources and the environmental conditions present during sediment deposition. The scales of these lithologic variations indicate that sedimentation in the Bering Sea has recorded long-term trends that include the critical period of reorganization of Earth's climate from the warm early Pliocene, and the transition into the ice ages. The physiographic settings of the different sites, their water depths, and their locations relative to the sediment source areas account for the marked regional differences in sediment composition, especially between the Pleistocene sections of the Bowers Ridge and the Bering slope sites.

The results of Exp 323 suggest that the history of sedimentation in the Bering Sea is broadly characterized by three main sedimentary phases that occurred between $\sim 5 \mathrm{Ma}$ and $\sim 2.7 \mathrm{Ma}, \sim 2.7 \mathrm{Ma}$ and $\sim 1.74 \mathrm{Ma}$, and $\sim 1.74 \mathrm{Ma}$ to recent (Fig. 4). The oldest portion of the sedimentary record ( $\sim 5 \mathrm{Ma}$ to $\sim 2.7 \mathrm{Ma}$ ) was retrieved only at Bowers Ridge Sites U1340 and U1341. As illustrated by the age vs depth curves, sedimentation rates during the early middle Pliocene were relatively high (Fig. 3) and characterized by diatom ooze with minor amounts of diatom silt, sponge spicules, and vitric ash. Although the Pliocene sediment is commonly bioturbated, distinct intervals characterized by extensive lamination also occur. The oldest laminated intervals $(<3.8 \mathrm{Ma})$ were observed at Site U1341, although the origin of the lami- 
nations, and whether they represent primary or secondary processes is unknown. Notably, especially in the deeper parts of the record, compaction or diagenetic phase transformations might have created secondary sedimentological features, overprinting the primary ones. Isolated ice rafted debris (IRD) pebbles were observed in sediments older than 3.8 Ma only at Site U1340. Limited dropstone occurrence prior to $2.7 \mathrm{Ma}$ was also reported at two sites drilled in the northern Pacific during Leg 145 (ODP Sites 881 and 883) and in the Yakataga Formation in Alaska (Lagoe et al., 1993), which suggests the development of Alpine glaciers prior to the onset of Northern Hemisphere glaciation (NHG) (Krissek, 1995).

The middle section of Sites U1340 and U1341 $(\sim 2.7-1.74 \mathrm{Ma})$ is characterized by beds of diatom ooze with minor amounts of calcareous nannofossils and foraminiferal ooze alternating with diatom silt beds. The latter are composed of subequal proportions of siliciclastic (silt-sized quartz, feldspar, and rock fragments and/or clay) and biogenic components and minor volcaniclastic components. Dropstone occurrence is common-indicating a peak in siliciclastic deposition that has also been observed at Leg 145 sites-and coincides with the beginning of NHG. However, the dramatic drop in paleoproductivity recorded at Site 882 (Haug et al., 1999) is not present at the Bowers Ridge sites where, conversely, the biogenic component is high throughout the late Pliocene and Pleistocene.

All sites drilled during Exp 323 preserve a record of sedimentation ranging from the early Pleistocene through the
Holocene (1.74 Ma to recent). Lithologies and sedimentation rates vary between the different sites, as indicated by a basin-wide comparison of the evolution of sedimentation in the Bering Sea during this period (Figs. 3, 4). The lowest sedimentation rates (only $4.5 \mathrm{~cm} \mathrm{k.y.-1}$ ) were observed at Site U1342, where laminated foraminifera-rich diatom ooze beds alternate with silty clay beds at timescales ranging in the Milankovitch band (Fig. 5). The same temporal interval corresponds to a much thicker section at Sites U1340 and U1341, where the bedding alternations are less distinct and the abundance of IRD is higher. Although lamination is common at Sites U1342 and U1340, laminae are virtually absent at the deeper Site U1341. At the Bering Sea slope site, sedimentation rates are about three times higher than at the Bowers Ridge sites. At Sites U1339, U1343, and U1344, siliciclastic-rich beds and mixed siliciclastic-biogenic beds alternate cyclically. The sections are pervasively bioturbated, and laminated intervals are rare. Overall, sedimentation on the Bering slope is characterized by higher influence of (1) siliciclastic material delivered by ice sheets and (2) terrigenous sedimentation derived from the continental shelf and slope, which are indented by some of the largest submarine canyons in the world. However, because of their proximity to the continents, it is not clear whether the sediments characterized by high siliciclastic content are recording periods of ice sheet expansion (stadials) or increased runoff (interstadials). IRD is a common feature at all sites during this time period, and it increases significantly in sediments younger than $1 \mathrm{Ma}$, as is also observed in coeval sediments from the North Pacific based on the results of Leg 145 (Krissek, 1995).

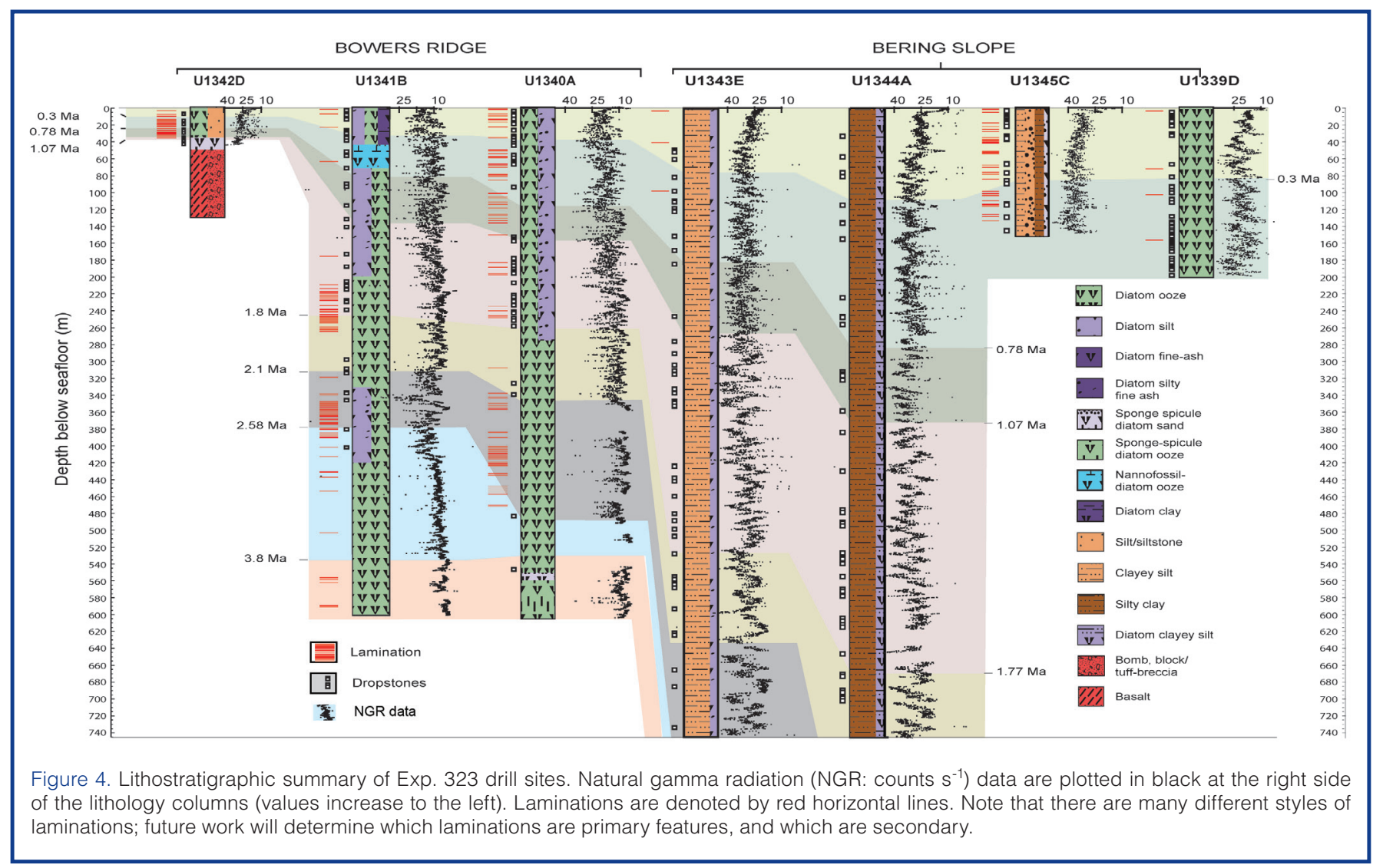




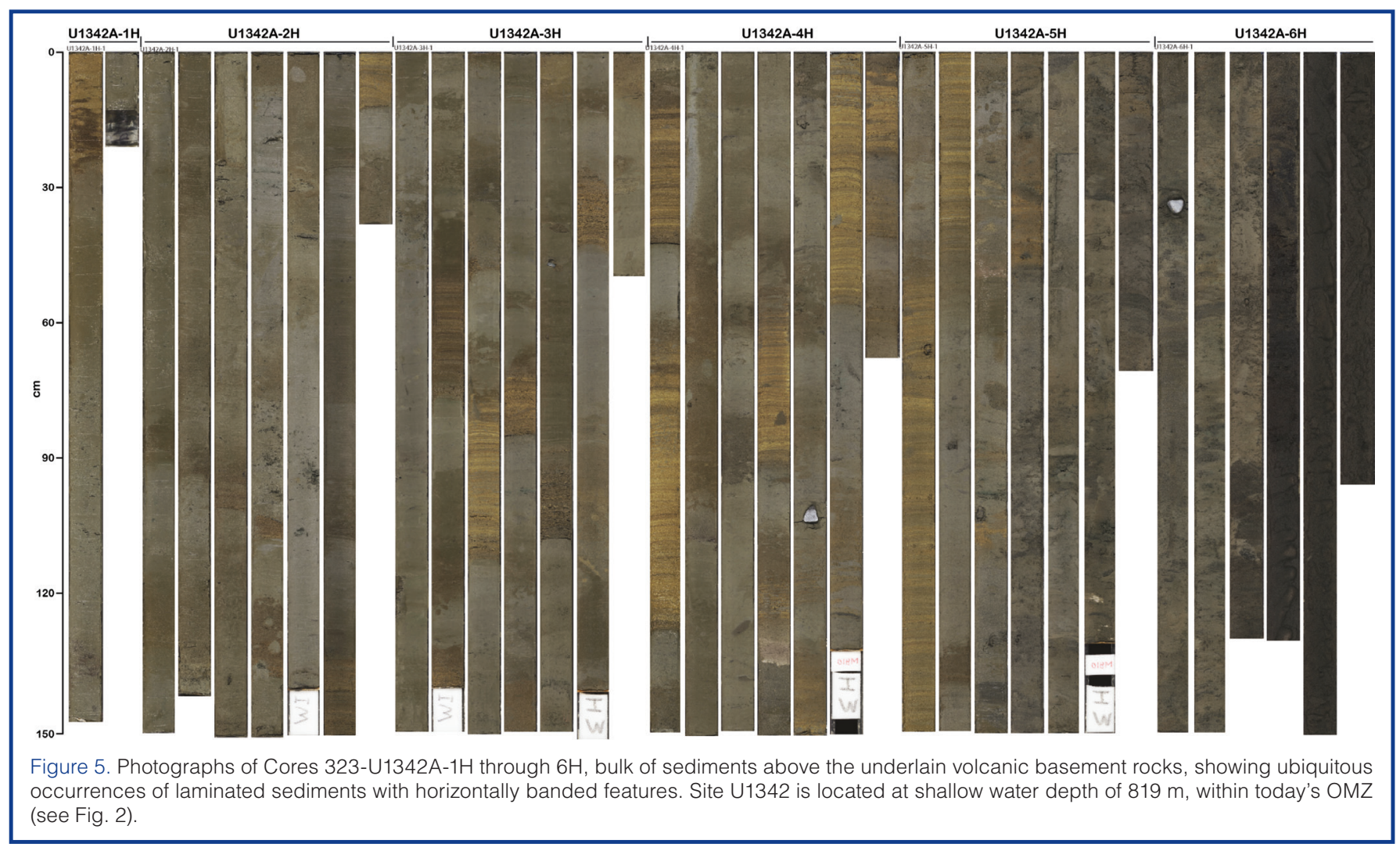

\section{History of Sea-Ice Development}

One of the most striking findings of Exp 323 is the general sea-ice distribution history of the Bering Sea for the past $5 \mathrm{Ma}$. As described earlier, the first sign of sea ice is the presence of pebbles, which are thought to be transported as IRD starting at $>3.8 \mathrm{Ma}$ at Site U1340 (Fig. 4), indicating the formation of sea ice or iceberg transportation to the Bowers Ridge region. The bulk of the evolution of sea-ice distribution has been interpreted from shipboard analyses of sea-ice diatoms and sea-ice-related dinoflagellate taxa and to a lesser extent by other diatom taxa and intermediate water-dwelling radiolarians.

The details of sea-ice evolution are derived from changes in the relative abundance of sea-ice diatom taxa, which are represented mainly by Thalassiosira antarctica spores (Abelmann, 1992a) and sea-ice dinoflagellates. The first signs of sea ice diatoms and dinoflagellates are subtle increases in their abundances at Bowers Ridge Site U1340, starting at $\sim 3.4$ Ma for dinoflagellates and $\sim 2.7$ Ma for diatoms, coincident with NHG (Maslin et al., 1996). Later than $\sim 2 \mathrm{Ma}$ the sea-ice assemblage signals become progressively stronger into the present, up to values of $\sim 10 \%-20 \%$ of the total respective assemblages. In contrast to the Bowers Ridge sites, sea-ice cover at the Bering slope sites is markedly severe, indicated by significantly higher sea-ice assemblage percentages. Sea-ice diatom values range from $~ 10 \%$ to $50 \%$ during the latest Pliocene and increase from 30\% to $70 \%$ during the Pleistocene. Notably, sea-ice diatom and dinoflagellate assemblages clearly show a significant increase in both abundance and amplitudes of variability around the
mid-Pleistocene Transition (MPT). Analogous to sea-ice-associated diatom and dinoflagellate taxa, a clear increasing trend in abundance of intermediate water-dwelling radiolarian taxa at the MPT is also observed at Sites U1343 and U1344. This is consistent with the interpretation that the surface water became gradually more affected by the formation of sea ice as climate progressively cooled; in the presence of sea ice, surface-dwelling radiolarians disappeared, and as a consequence, the relative percentages of intermediate water dwellers such as Cycladophora davisiana were higher (Abelmann, 1992b; Okazaki et al., 2003).

At Sites U1343 and U1344, which are located closer to the southern boundary of today's seasonal sea-ice maximum extent than the Bowers Ridge sites, a dramatic change in the dominance of dinoflagellate cyst assemblages from autotrophic to heterotrophic taxa is evident at $\sim 1.2-1.5 \mathrm{Ma}$. This suggests that sea-ice formation occurred well before the time when the abundance of sea-ice taxa significantly increased at $\sim 1 \mathrm{Ma}$. Along with significant increases of both sea-ice dinoflagellates and diatoms (e.g., T. antarctica spores) at $\sim 1 \mathrm{Ma}$ at both sites, there is a rather significant drop in the abundance of the typical pelagic diatom Neodenticula seminae. All of these biotic events are within the time interval of the MPT, which spans from $1.2 \mathrm{Ma}$ to $0.8 \mathrm{Ma}$ and marks the transition from 41 k.y. obliquity ice volume cycles to longer ice age cycles that vary at $100-k . y$. frequencies.

As noted above, the Bowers Ridge and Bering slope regions show distinct differences in the extent of sea-ice cover throughout the last $\sim 2.4 \mathrm{Ma}$. The extent of sea-ice cover of the latter was substantially greater than that of the 
former because of the proximal locations of the three Bering slope sites, which are most prone to perennial sea-ice cover in the Bering Sea. The spatial differences in sea-ice cover today are mainly attributed to the surface water circulation pattern; this spatial difference appears to have persisted for at least $2.4 \mathrm{Ma}$, implying that the surface water circulation patterns were comparable as well.

\section{Changes in Biological Productivity and Subarctic Pacific Water Mass Entry}

Based on the spatial distributions of long-term temporal changes of three diatom taxa (Coscinodiscus marginatus, Neodenticula, and Actinocyclus curvatulus), it is clear that the influence of subarctic Pacific waters, which are relatively warm and less eutrophic than Bering Sea waters, has typically been strongest at the Bowers Ridge sites, followed by the Umnak site. The weakest influence of this warm water mass has occurred at the Bering slope sites. The same pattern was found by Katsuki and Takahashi's (2005) study of past water mass circulation patterns, which they inferred from sea-ice distributions over the last glacial period. The wide-ranging records from Exp 323 indicate that as climate cooled through the Pleistocene, pelagic water influence at all the sites progressively weakened. Furthermore, the sites closest to straits through which pelagic water flows into the Bering Sea have consistently higher abundances of subarctic diatom species than those downstream of the counterclockwise circulation pattern of the surface water masses.

From the bottom of the holes upward at the Bowers Ridge sites, a marked drop in C. marginatus was seen at $\sim 2.8 \mathrm{Ma}$ at Site U1341 and at $2.6 \mathrm{Ma}$ at Site U1340. This can be interpreted as resulting from a sharp reduction in supply of nutrients due to the development of upper layer stratification. It is apparent that the diatom taxon $C$. marginatus requires a relatively high nutrient supply and tolerates low light intensity. This is substantiated by the fact that (1) today this diatom taxon dwells in the lower euphotic zone off Spain (Nogueira et al., 2000; Nogueira and Figueiras, 2005), and (2) it occurs during early winter (November-January) in the subarctic Pacific and the Bering Sea based on time-series sediment trapping (Takahashi, 1986; Takahashi et al., 1989; Onodera and Takahashi, 2009). This timing of 2.8-2.6 Ma coincides approximately with the so-called end of "opal dump" observed in the subarctic Pacific at $2.7 \mathrm{Ma}$, which is coincidental with the onset of NHG (Maslin et al., 1996). Although the reduction in $C$. marginatus around the time of NHG persisted, an overwhelmingly continuous presence of diatom ooze and interbedded diatom ooze and silt sediments accumulated throughout the Pliocene-Pleistocene in the Bering Sea. This clearly suggests that a high amount of opal sedimentation continued after the onset of NHG well into the Pleistocene.

The 5-Ma long-term trend of Neodenticula (N. kamtschatica, N. koizumii, N. seminae, and Neodenticula sp.) in the
Bowers Ridge region shows the following patterns. Generally higher percentages of Neodenticula in total diatoms are observed from the base of the holes towards younger ages until 2.8-2.7 Ma. After that, there is a decline in Neodenticula with sizable fluctuations, indicating that surface water stratification progressively developed as the climate cooled from the Pliocene into the Pleistocene. As surface waters became increasingly stratified, especially after $\sim 0.9 \mathrm{Ma}$ with Milankovitch-scale 100-k.y. climatic cyclic regimes, $N$. seminae declined with the emerging sea-ice diatoms.

\section{Changes in Bottom and Intermediate Water Conditions}

In order to elucidate the history, temporal variability, and intensity of NPIW and deepwater formation in the Bering Sea and its links to surface water processes, the insights provided by the investigation on benthic foraminifera and midwater radiolarians are prerequisites. The Bering Sea sites ranged from $818 \mathrm{~m}$ to $3174 \mathrm{~m}$ in depth, and they allow for characterization of past vertical water mass distribution and for reconstruction of the history of the $\mathrm{OMZ}$ distribution in the region (Fig. 2). Shipboard analyses of sediment samples during Exp 323 show continuous recovery of Pliocene to Holocene deep-sea benthic foraminifera and midwater radiolarians at all sites, although calcareous benthic foraminifera appear to be rare in the Pliocene. The benthic foraminifera composition displays large assemblage changes, likely related to variability in local bottom water oxygen concentration in the bottom waters associated with surface water productivity and/or deepwater ventilation on Milankovitch and shorter timescales. For example, Bulimina aff. exilis, a common species in Bering Sea samples, is generally regarded as a low oxygen/deep infaunal species and has been found in samples associated with high productivity and low sea ice (Bubenshchikova et al., 2008; Kaiho, 1994).

Previous piston core studies showed a large increase in the intensity of the $\mathrm{OMZ}$ during the last deglacial at Umnak Plateau (Okazaki et al., 2005), suggesting a relationship between productivity and terrestrial nutrient supply from melting ice and increased river input. However, there is no information regarding the longer timescale relationship through the Pleistocene. Analysis of fauna from the newly drilled Bering Sea sites will be particularly important in extending this record through the entire Pliocene (at Bowers Ridge) and Pleistocene (at Bowers Ridge and the Bering slope). It will allow us to decipher the onset and evolution of the $\mathrm{OMZ}$ and provide further insight into NPIW production in this marginal sea. Furthermore, Site U1344 at $\sim 3200 \mathrm{~m}$ (presently located below the OMZ) has the potential to provide records of past deepwater changes.

A striking finding of the expedition was the relatively low oxygen content of intermediate water mass conditions at most sites during the last $5 \mathrm{Ma}$, as indicated by the presence of episodic laminated sediment intervals throughout the 
entire record. The benthic foraminifera Martinottiella communis occurred persistently in the Pliocene. The cooccurrence of other low oxygen species (e.g., Bulimina aff. mexicana), together with the modern distribution of $M$. communis in OMZs, indicates low oxygen conditions persisted throughout the last $5 \mathrm{Ma}$. However $M$. communis is not recorded in the Bering Sea after $2 \mathrm{Ma}$, suggesting changes to deepwater properties after this time. Abundant calcareous benthic species occur after $\sim 2$ Ma (e.g., Bulimina, Globobulimina, Islandiella, Nonionella, and Valvulineria) that are typically indicative of very low oxygen conditions (Bubenshchikova et al., 2008).

High sediment accumulation rate at Sites U1339 and U1345, located within the current OMZ (Figs. 2, 4), reveal high-amplitude variability in the relative abundance of the deep infaunal assemblage for the past $0.8 \mathrm{Ma}$. This appears to be associated with interglacial-deglacial cyclicity, represented by higher abundance of deep infaunal species (reflecting the lowest bottom water oxygen conditions) during interglacials. This particularly true during the strong interglacial-like Marine Isotope Stages (MIS) 1, 5, and 11. Higher bottom water oxygen concentrations appear to correlate with some glacial periods. Sites U1340, U1343, and U1344 contain well-preserved foraminifera over the last $2 \mathrm{Ma}$ with increasing absolute abundances of benthic and planktonic taxa across the MPT ( 0.8-1.1 Ma) in association with an increase in abundance of the polar planktonic foraminifera Neogloboquadrina pachyderma. This cooling trend was also observed as an increase in the abundance of sea-ice dinoflagellates and diatoms and coincided with increasing intermediate water-dwelling radiolarians (e.g., C. davisiana). Cooling of the surface waters would have enhanced ventilation of the intermediate waters during glacials and would have increased density stratification during interglacials, contributing to a drop in oxygen content in the intermediate and bottom waters at these times. Such a decrease in oxygen content is supported by a possible increase in deep infaunal benthic foraminifera taxa at Sites U1343 and U1344 over the MPT, but higher resolution sampling from existing core material is needed to resolve this.

\section{Microbiology and Geochemistry in High Surface Productivity Environments}

The microbiological objectives of Exp 323 were to constrain global models of subseafloor biomass and microbial respiration by quantifying subseafloor cell abundance and pore water chemistry in an extremely high productivity region of the ocean. We also sought to determine how subseafloor community composition is influenced by high productivity in the overlying water column. To meet these objectives, high-resolution sampling for microbiological analyses and pore water chemistry took place at five sites throughout the Bering Sea. Each site was selected based upon its distance from land and its levels of marine productivity determined by annual chlorophyll-a concentrations in the water column.

The geochemical data obtained during the expedition show that the present-day microbial activity along the slope sites (Sites U1339, U1343, U1344, and U1345) is substantially higher and more diverse in terms of respiration pathways than at Bowers Ridge (Sites U1340, U1341, and U1342). At the slope sites, the concentrations of microbial respiration products such as dissolved inorganic carbon (DIC), ammonium, and phosphate are approximately an order of magnitude higher than at Bowers Ridge (Fig. 6). A shallow sulfatemethane transition zone (SMTZ) $(\sim 6-11 \mathrm{~m} \mathrm{mbsf})$ is also present, indicating that both methanogenesis and sulfate reduction based on methane oxidation occur in these sediments. Pore water data suggest the presence of microbially

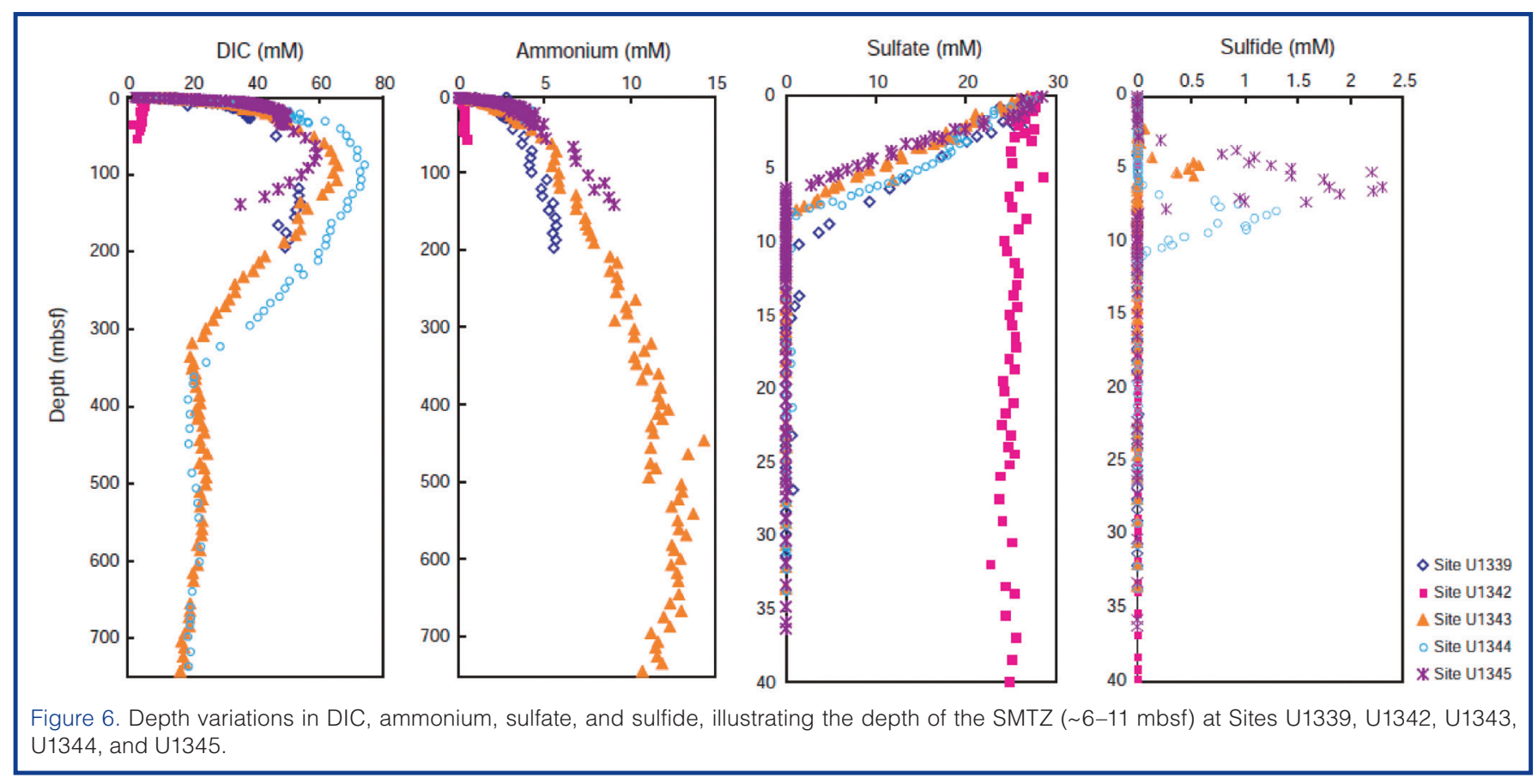


mediated Fe and Mn reduction. The geochemical profiles also indicate significant microbial activity as deep as 700 mbsf. In contrast, at Bowers Ridge sulfate penetrates to the basement and is almost unaltered with depth, suggesting only very low rates of microbially mediated sulfate reduction. Methane is mostly below detection limit. The differences in microbial activity at these sites may be caused by differences in water column productivity and sedimentation patterns.

We expect that the differ-ences in the geochemical parameters between the slope and ridge sites will be reflected in microbial abundance and diversity. A larger and more diverse microbial community at the slope sites is likely. Specifically, we expect elevated cell density and an assemblade of bacteria and archaea at the SMTZ. At the slope sites, geochemical profiles suggest that methanogens, iron reducers, manganese reduc-ers, and sulfate reducers exist throughout the sediment column. At Bowers Ridge, geochemical profiles indicate that, at present, diagenetic processes are dominated by nitrate, manganese and iron reducers, while sulfate reducers and methanogens are of minor importance.

\section{Acknowledgements}

We thank the captain, operation superintendent, crew, and technicians who assisted us in drilling and sample analyses during Exp 323. Numerous people at IODP-TAMU as the USIO provided their dedicated effort supporting us, including preparation of the expedition and publication of the proceedings. We also thank the crucial members of ODP and IODP Proposal 477, which was initially written and submitted in 1995; without their cooperation this project could have never been materialized. This includes their effort during the site survey cruise on $\mathrm{R} / \mathrm{V}$ Hakuho-Maru which took place in 1999 as well as the data processing performed afterwards. The curatorial team provided us with their able support during the two time sampling parties at the Kochi Core Center of JAMSTEC. We also thank the following reviewers for their constructive comments on the manuscript: Hans Christian Larsen, Ulrich Harms, Jamus Collier, Mika Saido, Renata Szarek, and Glen Hill.

\section{The IODP Expedition 323 Scientists}

K. Takahashi (Co-Chief Scientist), A.C. Ravelo (Co-Chief Scientist), C. Alvarez Zarikian (Staff Scientist), I. Aiello, H. Asahi, G. Bartoli, B. Caissie, M. Chen, E. ColmeneroHidalgo, M. Cook, K. Dadd, G. Guèrin, Y. Huh, K. Husum, A. Ijiri, M. Ikehara, S. Kender, T. Liu, S. Lund, C. März, A. Mix, M. Ojha, M. Okada, Y. Okazaki, J. Onodera, C. Pierre, T. Radi, N. Risgaard-Petersen, T. Sakamoto, D. Scholl, H. Schrum, Z.N. Stroynowski, E.A. Walsh, and L. Wehrmann.

\section{References}

Abelmann, A., 1992a. Diatom assemblages in Arctic sea ice-indicator for ice drift pathways. Deep-Sea Res., Part A Oceanogr. Res. Papers, 39(2-1):S525-S538, doi:10.1016/S0198-0149 (06)80019-1.

Abelmann, A., 1992b. Radiolarian flux in Antarctic waters (Drake Passage, Powell Basin, Bransfield Strait). Polar Biol., 12(3-4):357-372, doi:10.1007/BF00243107.

Berger, W.H., 1970. Biogenous deep-sea sediments: fractionation by deep-sea circulation. Geol. Soc. Am. Bull., 81(5):1385-1402, doi:10.1130/0016-7606(1970)81[1385:BDS-FBD]2.0.CO;2.

Bubenshchikova, N., Nürnberg, D., Lembke-Jene, L., and Pavlova, G., 2008. Living benthic foraminifera of the Okhotsk Sea: faunal composition, standing stocks and microhabitats. Mar. Micropaleontol., 69(3-4):314-333, doi:10.1016/j.marmicro. 2008.09.002.

Cook, M.S., Keigwin, L.D., and Sancetta, C.A., 2005. The deglacial history of surface and intermediate water of the Bering Sea. Deep-Sea Res., Part II Topical Studies Oceanogr., 52(16-18):2163-2173, doi:10.1016/j.dsr2.2005.07.004.

Expedition 323 Scientists, 2010. Bering Sea paleoceanography: Pliocene-Pleistocene paleoceanography and climate history of the Bering Sea. IODP Prel. Rept., 323, doi:10.2204/ iodp.pr.323.2010.

Gorbarenko, S.A., 1996. Stable isotope and lithological evidence of late glacial and Holocene oceanography of the northwestern Pacific and its marginal seas. Quat. Res., 46(3):230-250, doi:10.1006/qres.1996.0063.

Gradstein, F.M., Ogg, J.G., and Smith, A.G., 2004. A Geologic Time Scale 2004: Cambridge (Cambridge University Press).

Haug, G.H., Sigman, D.M., Tiedemann, R., Pedersen, T.F., and Sarnthein, M., 1999. Onset of permanent stratification in the subarctic Pacific Ocean. Nature (London, U.K.), 401(6755):779-782, doi:10.1038/44550.

Hendy, I.L., and Kennett, J.P., 2003. Tropical forcing of North Pacific intermediate water distribution during late Quaternary rapid climate change? Quat. Sci. Rev., 22(5-7):673-689, doi:10.1016/S0277-3791(02)00186-5.

Honjo, S., 1990. Particle fluxes and modern sedimentation in the polar oceans. In Smith, W.O., Jr. (Ed.), Polar Oceanography (Pt. B): Chemistry, Biology, and Geology: New York (Academic), 687-739.

Hood, D.W., 1983. The Bering Sea. In Ketchum, B.H. (Ed.), Estuaries and Enclosed Seas: The Netherlands (Elsevier), 337-373.

Kaiho, K., 1994. Benthic foraminiferal dissolved-oxygen index and dissolved-oxygen levels in the modern ocean. Geology, 22(8):719-722, doi:10.1130/ 0091-7613(1994) 022<0719:BFD OIA $>2.3 . \mathrm{CO} ; 2$.

Katsuki, K., and Takahashi, K., 2005. Diatoms as paleoenvironmental proxies for seasonal productivity, sea-ice and surface circulation in the Bering Sea during the late Quaternary. Deep-Sea Res., Part II Topical Studies Oceanogr., 52(16-18):2110-2130, doi:10.1016/j.dsr2.2005.07.001.

Krissek, L.A., 1995. Late Cenozoic ice-rafting records from Leg 145 sites in the North Pacific: late Miocene onset, late Pliocene intensification, and Pliocene-Pleistocene events. In Rea, D.K., Basov, I.A., Scholl, D.W., and Allan, J.F. (Eds.), Proc. ODP, Sci. Results, 145: College Station, TX (Ocean Drilling Program), 179-194. doi:10.2973/odp/proc.sr.145.118.1995. 
Lagoe, M.B., Eyles, C.H., Eyles, N., and Hale, C., 1993. Timing of late Cenozoic tidewater glaciation in the far North Pacific. Geol. Soc. Am. Bull., 105(12):1542-1560, doi:10.1130/ 0016-7606 (1993) 105<1542:TOLCTG>2.3.CO;2.

Lehmann, M.F., Sigman, D.M., McCorkle, D.C., Brunelle, B.G., Hoffmann, S., Kienast, M., Cane, G., and Clement, J., 2005. Origin of the deep Bering Sea nitrate deficit: constraints from the nitrogen and oxygen isotopic composition of water column nitrate and benthic nitrate fluxes. Global Biogeochem. Cycles, 19(4):GB4005, doi:10.1029/2005GB 002508 .

Maslin, M.A., Haug, G.H., Sarnthein, M., and Tiedemann, R., 1996. The progressive intensification of Northern Hemisphere glaciation as seen from the North Pacific. Geol. Rundsch., 85(3):452-465, doi:10.1007/BF02369002.

Matsumoto, K., Oba, T., Lynch-Stieglitz, J., and Yamamoto, H., 2002. Interior hydrography and circulation of the glacial Pacific Ocean. Quat. Sci. Rev., 21(14-15):1693-1704, doi:10.1016/ S0277-3791(01)00142-1.

Nedashkovskiy, A.P., and Sapozhnikov, V.V., 1999. Variability in the components of the carbonate system and dynamics of inorganic carbon in the western Bering Sea in summer. In Loughlin, T.R., and Ohtani, K. (Eds.), Dynamics of the Bering Sea. A Summary of Physical, Chemical, and Biological Characteristics, and a Synopsis of Research on the Bering Sea: Fairbanks (University of Alaska Sea Grant), 311-322.

Nogueira, E., and Figueiras, F.G., 2005. The microplankton succession in the Ria de Vigo revisited: species assemblages and the role of weather-induced, hydrodynamic variability. $J$. Mar. Syst., 54(1-4):139-155, doi:10.1016/j.jmarsys.2004. 07.009 .

Nogueira, E., Ibanez, F., and Figueiras, F.G., 2000. Effect of meteorological and hydrographic disturbances on the microplankton community structure in the Ría de Vigo (NW Spain). Mar. Ecol. Prog. Ser., 203:23-45, doi:10.3354/meps203023.

Ohtani, K., 1965. On the Alaskan Stream in summer. Bull. Fac. Fish., Hokkaido Univ., 15:260-273. (In Japanese).

Okazaki, Y., Takahashi, K., Asahi, H., Katsuki, K., Hori, J., Yasuda, H., Sagawa, Y., and Tokuyama, H., 2005. Productivity changes in the Bering Sea during the late Quaternary. Deep-Sea Res., Part II Topical Studies Oceanogr., 52(1618):2150-2162, doi:10.1016/j.dsr2.2005.07.003.

Okazaki, Y., Takahashi, K., Yoshitani, H., Nakatsuka, T., Ikehara, M., and Wakatsuchi, M., 2003. Radiolarians under the seasonally sea-ice covered conditions in the Okhotsk Sea: flux and their implications for paleoceanography. Mar. Micropaleontol., 49(3):195-230, doi:10.1016/S0377-8398(03) 00037-9.

Onodera, J., and Takahashi, K. 2009. Long-term diatom fluxes in response to oceanographic conditions at Stations $\mathrm{AB}$ and SA in the central subarctic Pacific and the Bering Sea, 19901998. Deep-Sea Research I, 56(2):189-211. doi:10.1016/j. dsr.2008.08.006.

Sambrotto, R.N., Goering, J.J., and McRoy, C.P., 1984. Large yearly production of phytoplankton in the western Bering Strait. Science, 225(4667):1147-1150, doi:10.1126/science.225. 4667.1147.

Scholl, D.W., and Creager, J.S., 1973. Geologic synthesis of Leg 19 (DSDP) results; far North Pacific, and Aleutian Ridge, and Bering Sea. In Creager, J.S., Scholl, D.W., et al., Init. Repts.
$D S D P$, 19: Washington, DC (U.S. Govt. Printing Office), 897-913, doi:10.2973/dsdp.proc.19.137.1973.

Solomon, S., Qin, D., Manning, M., Marquis, M., Averyt, K., Tignor, M.M.B., Miller, H.L., Jr., and Chen, Z., 2007. Climate Change 2007: The Physical Science Basis: Cambridge (Cambridge University Press).

Stabeno, P.J., Schumacher, J.D., and Ohtani, K., 1999. The physical oceanography of the Bering Sea. In Loughlin, T.R., and Ohtani, K. (Eds.), Dynamics of the Bering Sea: A Summary of Physical, Chemical, and Biological Characteristics, and a Synopsis of Research on the Bering Sea: Fairbanks (University of Alaska Sea Grant), 1-28.

Takahashi, K., 1986. Seasonal fluxes of pelagic diatoms in the subarctic Pacific, 1982-1983. Deep-Sea Res., Part A Oceanogr. Res. Papers, 33:1225-1251, doi:10.1016/0198-0149(86)90022-1.

Takahashi, K., 2005. The Bering Sea and paleoceanography. DeepSea Res., Part II Topical Studies Oceanogr., 52(16-18):20802091, doi:10.1016/j.dsr2.2005.08.003.

Takahashi, K., Honjo, S., and Tabata, S., 1989. Siliceous phytoplankton flux: interannual variability and response to hydrographic changes in the northeastern Pacific. In Peterson, D. (Ed.), Aspects of Climate Variability in the Pacific and Western Americas. Geophys. Monogr., 151-160.

Takahashi, K., Jordan, R.W., and Boltovskoy, D., 2005. Deep-Sea Res., Part II Topical Studies Oceanogr., 52(16-18):2079-2364, doi:10.1016/j.dsr2.2005.08.002.

Takahashi, K., Ravelo, A.C., Alvarez Zarikian, C.A., and the Expedition 323 Scientists. 2011. Proc. IODP, 323: Tokyo Integrated Ocean Drilling Program Management International, Inc.), doi:10.2204/iodp.proc.323.2011.

Tanaka, S., and Takahashi, K., 2005. Late Quaternary paleoceanographic changes in the Bering Sea and the western subarctic Pacific based on radiolarian assemblages. Deep-Sea Res., Part II Topical Studies Oceanogr., 52(16-18):2131-2149, doi:10.1016/j.dsr2.2005.07.002.

Warner, M.J., and Roden, G.I., 1995. Chlorofluorocarbon evidence for recent ventilation of the deep Bering Sea. Nature (London, U.K.), 373(6513):409-412, doi:10.1038/373409a0.

\section{Authors}

Kozo Takahashi, Department of Earth \& Planetary Sciences, Graduate School of Sciences, Kyushu University, Hakozaki 6-10-1, Higashi-ku, Fukuoka 812-8581, Japan, e-mail:kozo@geo.kyushu-u.ac.jp.

A. Christina Ravelo, Ocean Sciences Department, University of California, 1156 High Street, Santa Cruz, CA 95064, U.S.A.

Carlos Alvarez Zarikian, Integrated Ocean Drilling Program \& Department of Oceanography, Texas A\&M University, 1000 Discovery Drive, College Station, TX 77845-9547, U.S.A.

and the IODP Expedition 323 Scientists

\section{Related Web Link}

http://www.iodp.tamu.edu/scienceops/expeditions/bering_sea.html 